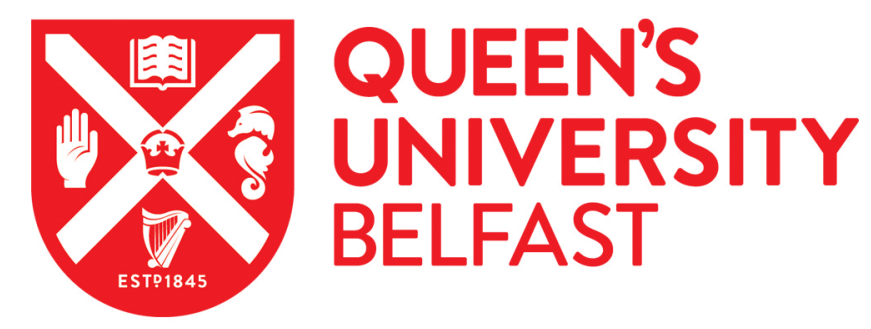

\title{
Formation of Ketenimines via the Palladium-Catalyzed Decarboxylative T-Allylic Rearrangement of N-Alloc Ynamides
}

Alexander, J. R., \& Cook, M. J. (2017). Formation of Ketenimines via the Palladium-Catalyzed Decarboxylative $\pi$-Allylic Rearrangement of N-Alloc Ynamides. Organic Letters, 19(21), 5822-5825.

https://doi.org/10.1021/acs.orglett.7b02780

\section{Published in:}

Organic Letters

Document Version:

Peer reviewed version

Queen's University Belfast - Research Portal:

Link to publication record in Queen's University Belfast Research Portal

Publisher rights

Copyright $\odot 2017$ American Chemical Society. This work is made available online in accordance with the publisher's policies. Please refer to any applicable terms of use of the publisher.

\section{General rights}

Copyright for the publications made accessible via the Queen's University Belfast Research Portal is retained by the author(s) and / or other copyright owners and it is a condition of accessing these publications that users recognise and abide by the legal requirements associated with these rights.

Take down policy

The Research Portal is Queen's institutional repository that provides access to Queen's research output. Every effort has been made to ensure that content in the Research Portal does not infringe any person's rights, or applicable UK laws. If you discover content in the Research Portal that you believe breaches copyright or violates any law, please contact openaccess@qub.ac.uk. 


\title{
Formation of Ketenimines via the Palladium Catalyzed Decarboxyla- tive $\pi$-Allylic Rearrangement of $\boldsymbol{N}$-Alloc Ynamides
}

\author{
Juliana R. Alexander ${ }^{\dagger, *}$ and Matthew J. Cook ${ }^{\dagger,+*}$
}

School of Chemistry and Chemical Engineering, Queen's University Belfast, Belfast BT9 5AG, Northern Ireland and Department of Chemistry and Biochemistry, Montana State University, Bozeman MT 59717.

matthewcook@montana.edu

Supporting Information Placeholder

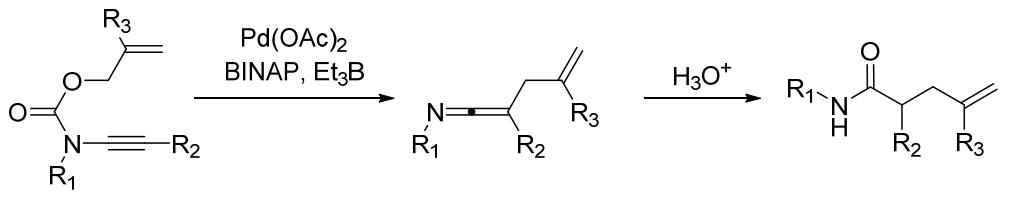

\begin{abstract}
A new approach for the formation of ketenimines has been developed via a decarboxylative allylic rearrangement pathway which does not require strong stabilizing or protecting groups. These can be readily hydrolyzed into their corresponding secondary amides or reacted with sulfur ylides to perform an additional [2,3]-Wittig process. Mechanistic studies have also been performed and suggest an outer-sphere process where reductive alkylation is rate limiting.
\end{abstract}

Ketenimines are versatile compounds that are underutilized in synthesis due to the relatively few general methods for their synthesis. These heteroallenic species contain an electrophilic sp-hydridized central carbon and exhibit similar reactivity to ketenes, undergoing nucleophilic and radical additions alongside pericyclic pathways such as cycloadditions, electrocyclizations and [1,3]-shifts. Ketenimines are generally more stable than ketenes and can be further stabilized by heteroatom substitution (namely sulfur, phosphorus and silicon) and also via mesomeric groups. ${ }^{1}$ Although they can be chiral, there exists a linear nitrilium resonance form which leads to a very rapid epimerization. With all carbon substituted groups, this barrier is just 9-12 $\mathrm{kcal} / \mathrm{mol}^{2}$ The preparation of functionalized ketenimines can be troublesome due to both their high reactivity and the harsh reaction conditions required for their construction. Common methods include: the aza-Wittig reaction with ketenes, ${ }^{3}$ Wittig reactions of isocyanates $;{ }^{4}$ base mediated elimination of $S, N$-ketene acetals $;{ }^{5}$ iminoyl chlorides, ${ }^{6}$ iminoyl cyanides $;{ }^{7} \alpha$-halo iminoyl cyanides ${ }^{8}$ and aminoacrylonitriles; ${ }^{9}$ the dehydration of amides ${ }^{10}$ and thioamides $;{ }^{11}$ Beckman rearrangements, ${ }^{12}$ alkylation of nitriles ${ }^{13}$ and the deprotonation of nitriles followed by silylation. ${ }^{14}$ These methods are very effective; however, they generally require strong acid, base or strongly alkylating conditions. As a result, new reactions to form ketenimines that are functional group tolerant, allow a wide range of substituents, and occur under neutral conditions are highly desirable.

Following from our previous report on the decarboxylative rearrangement of $\mathrm{N}$-alloc indoles to form indolenines, ${ }^{15}$ we envisaged an analogous pathway to ketenimines. ${ }^{16}$ The rearrangement of $\mathrm{N}$-alloc ynamides would provide ketenimines in a very rapid manner using a functional group tolerant palladium catalyst under neutral conditions. Hsung had previously reported the rearrangement of $N$-allyl- $N$-tosyl ynamides, both thermally and palladium catalyzed, to provide the corresponding ketenimine that could be subsequently trapped by an exogenous nucleophile such as an amine or alcohol (Scheme 1). ${ }^{17}$ Although this reaction is very effective, many substrates reported contain a TIPS group at the terminal position of the ynamide. In the absence of this group, an $\mathrm{N}$-C tosyl migration occurs forming the corresponding nitrile. These issues could be remedied by performing an aza-Rautenstrauch rearrangement or through the use of the phosphoryl analog which suppressed this pathway. ${ }^{18}$

Scheme 1. Outer versus Inner-Sphere Mechanism and New Amide Disconnection.

Hsung (ref 17): Inner Sphere Mechanism

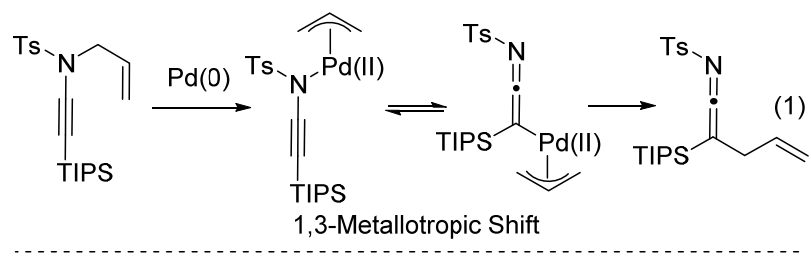

This Work: Outer Sphere Mechanism

- $\mathrm{Br}$ 
Hsung proposed that this transformation proceeds via the oxidative addition into the carbon-nitrogen bond which provides an imido- $\pi$-allyl complex which undergoes a 1,3-metallotropic shift followed by reductive elimination. We hypothesized that a more facile method to generate the $\pi$-allyl intermediate was to utilize an $\mathrm{N}$-alloc group and perform a decarboxylative rearrangement. ${ }^{19}$ This would proceed via an ynamide anion, following decarboxylation, which could be stabilized, as a borate complex, by the addition of a borane additive, a strategy we utilized with indoles. ${ }^{15}$ The synthesis of $N$-alloc ynamides can be easily achieved through a copper catalyzed coupling of the carbamate and the corresponding alkynyl bromide. ${ }^{20}$ The presence of the carbamate would acidify the N-H group during the coupling step, thus negating the need for an electron withdrawing group, such as tosyl. Hydrolysis of the ketenimine to the corresponding amide would provide a new disconnection for amide bond synthesis from an alloc carbamate and an alkynyl bromide.

\section{Table 1. Optimization Studies}

\begin{tabular}{|c|c|c|c|}
\hline Bu & $\begin{aligned} \text { 1) } 5 \mathrm{~mol} \% \mathrm{Pd}(\mathrm{OAc})_{2} \\
6 \mathrm{~mol} \% \mathrm{rac}-\mathrm{BINAP} \\
1 \text { equiv. } \mathrm{BEt}_{3} \\
\text { toluene, } 50^{\circ} \mathrm{C}, 1 \mathrm{~h} \\
\text { 2) } \mathrm{HCl} \text {, acetone } / \mathrm{H}_{2} \mathrm{O}\end{aligned}$ & $7 \%$ & $\begin{array}{c}\mathrm{Bu} \\
\mathbf{3}, 0 \%\end{array}$ \\
\hline entry & difference from optimized conditions & $2 \mathrm{a}: 3^{\mathrm{a}}$ & yield $/ \%^{b}$ \\
\hline 1 & No Change & $100: 0$ & $100(77)^{c}$ \\
\hline 2 & $\mathrm{No} \mathrm{BEt}_{3}$ & $45: 55$ & 100 \\
\hline 3 & $\begin{array}{l}5 \mathrm{~mol}^{2} \mathrm{Pd}_{2} \mathrm{dba}_{3} \cdot \mathrm{CHCl}_{3}, \\
11 \% \mathrm{~mol} \% \text { BINAP, } 21 \mathrm{~h}\end{array}$ & $85: 15$ & 100 \\
\hline 4 & $\mathrm{Pd}\left(\mathrm{PPh}_{3}\right)_{4}$ & $15: 85$ & 100 \\
\hline 5 & $\mathrm{Pd}\left(\mathrm{PPh}_{3}\right)_{4}, \mathrm{CH}_{2} \mathrm{Cl}_{2}, 25^{\circ} \mathrm{C}, 21 \mathrm{~h}$ & $0: 100$ & 96 \\
\hline 6 & {$[\mathrm{Pd}(\mathrm{allyl}) \mathrm{Cl}]_{2}, 19 \mathrm{~h}$} & $86: 14$ & 37 \\
\hline 7 & $\mathrm{Pd}(\mathrm{OTFA})_{2}, 19 \mathrm{~h}$ & $99: 1$ & 64 \\
\hline 8 & $\mathrm{Pd}(\mathrm{OTFA})_{2}$, No BEt & $100: 0$ & 44 \\
\hline 9 & $\begin{array}{l}\mathrm{Pd}(\mathrm{OTFA})_{2}, 10 \mathrm{~mol} \% \text { TFA instead o } \\
1 \text { Equiv. } \mathrm{BEt}_{3}, 21 \mathrm{~h}\end{array}$ & $100: 0$ & 53 \\
\hline 10 & $\begin{array}{l}{[\mathrm{Pd}(\text { allyl }) \mathrm{Cl}]_{2}, 10 \mathrm{~mol} \% \text { TFA instead }} \\
\text { of } 1 \text { Equiv. } \mathrm{BEt}_{3}, 22 \mathrm{~h}\end{array}$ & $100: 0$ & 29 \\
\hline
\end{tabular}

${ }^{a}$ Ratio determined by ${ }^{1} \mathrm{H}$ NMR of the crude; ${ }^{b}$ combined yield of 2a:3 determined by ${ }^{1} \mathrm{H}$ NMR analysis against a known amount of DMF as internal standard which was added to the reaction mixture following workup and immediately prior to preparation of the NMR sample; ${ }^{c}$ isolated yield of $\mathbf{2 a}$.

Our optimized conditions utilized a $\mathrm{Pd}(\mathrm{OAc})_{2} / \mathrm{BINAP}$ system with triethylborane as a Lewis acidic additive to stabilize the intermediate anion, in toluene (Table 1, entry 1). The crude reaction was monitored at this stage to determine the product ratios and conversions. As the ketenimines were somewhat unstable these were immediately hydrolyzed to the corresponding secondary amides prior to isolation and the optimized conditions led to $77 \%$ isolated yield. When the triethylborane is removed, a loss of selectivity was observed giving a near equal ratio of $C$ and $N$ allylated products (entry 2). Modulation of the catalyst resulted in different product ratios. $\mathrm{Pd}_{2} \mathrm{dba}_{3} \cdot \mathrm{CHCl}_{3}$ gives eroded selectivity (entry 3 ), and the use of $\mathrm{Pd}\left(\mathrm{PPh}_{3}\right)_{4}$ favors $N$-selectivity (entry 4 ), which can be rendered exclusively $\mathrm{N}$-selective through modulation of solvent and temperature (entry 5). $\left[\mathrm{Pd}(\text { allyl)Cl }]_{2}\right.$ was much slower to react (entry 6), giving a similar product ratio to $\mathrm{Pd}_{2} \mathrm{dba}_{3} \cdot \mathrm{CHCl}_{3}$. Complete $C$-selectivity was restored with $\operatorname{Pd}(\mathrm{OTFA})_{2}$, albeit in reduced conversion (entry 7). Interestingly, when the reaction is performed in the absence of triethylborane, selectivity is retained (entry 8). We attribute this to trace amounts of trifluoroacetic acid in the catalyst. This was confirmed by the addition of $10 \mathrm{~mol} \%$ of trifluoroacetic acid to both $\mathrm{Pd}(\mathrm{OTFA})_{2}$ (entry 9) and $\left[\mathrm{Pd}(\text { allyl) } \mathrm{Cl}]_{2}\right.$ (entry 10) in

\section{Scheme 2. Substrate Scope}

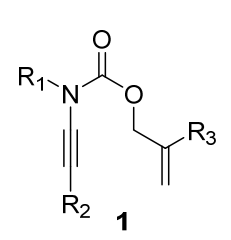

1) $5 \mathrm{~mol} \% \mathrm{Pd}(\mathrm{OAc})_{2}$

$6 \mathrm{~mol} \%$ rac-BINAP

1 equiv. $\mathrm{Et}_{3} \mathrm{~B}$

toluene $50^{\circ} \mathrm{C}$

2) $\mathrm{HCl}$, acetone, $\mathrm{H}_{2} \mathrm{O}$

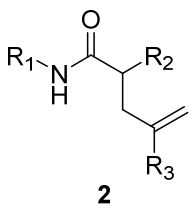<smiles>C=CCC(Br)C(=O)Nc1ccccc1</smiles>

2a, $77 \%^{a}$<smiles>C=CCC(Br)C(=O)Nc1ccc(F)cc1</smiles>

2b, $89 \%^{a}$<smiles>C=CCC(Br)C(=O)Nc1ccc(C(F)(F)F)cc1</smiles>

2c, $64 \%^{a}$<smiles>C/C=C\C(CC(C)C)C(=O)Nc1ccc(OC)cc1</smiles>

2d, $70 \%^{a}$<smiles>C=CCC(CC(C)C)C(=O)Nc1cc(OC)c(OC)c(OC)c1</smiles>

2e, $74 \%^{a}$<smiles>C=CCC(CC(C)C)C(=O)NCc1ccccc1</smiles>

2f, $56 \%^{a}$<smiles>C=CCC(CCC(C)(C)C)C(=O)Nc1ccccc1</smiles>

2g, $78 \%^{a}$<smiles>C=CCC(CCc1ccccc1)C(=O)Nc1ccccc1</smiles>

2h, $83 \%^{a}$<smiles>C=CCC(C(=O)Nc1ccccc1)C1CC1</smiles>

2i, $69 \%^{a}$<smiles>C=CCC(C(=O)Nc1ccccc1)C(C)(C)O[Sb](C)(C)C</smiles>

2j, $54 \%^{a}$<smiles>C=CCC(C(=O)Nc1ccccc1)c1ccccc1</smiles>

2k, $73 \%^{a}$<smiles>C=CCC(C(=O)Nc1ccc(F)cc1)c1ccccc1</smiles>

2I, $81 \%^{a}$<smiles>C=CCC(C(=O)Nc1ccc(OC)cc1)c1ccccc1</smiles>

2m, $67 \%^{a}$<smiles>COc1cc(NC(=O)C(C/C=C\[O+])c2ccccc2)cc(OC)c1OC</smiles>

2n, $76 \%^{\circ}$<smiles>C=CCC(C(=O)NCc1ccccc1)c1ccccc1</smiles>

2o, $70 \%^{a}$<smiles>C=C(C)CC(C(=O)Nc1ccccc1)C(=O)c1ccccc1</smiles>

2p, $67 \%^{a}$<smiles>C=C(C)CC(CCc1ccccc1)C(=O)Nc1ccccc1</smiles>

2q, $64 \%^{a}$<smiles>C=C(C)CC(C(=O)Nc1ccccc1)c1ccccc1</smiles>

${ }^{a}$ Isolated yields following hydrolysis.

the absence of triethylborane, both reactions proved completely selective. As a chiral ligand was utilized, the enantiopure variant was attempted which led to racemic product presumably due to the very low barrier to epimerization. ${ }^{2}$

With the optimized conditions in hand, we began examining the substrate scope (Scheme 2). We examined substitution on the 
carbamate, alkyne and allylic group and found that changes at all of these positions can be tolerated. We discovered that the aryl group can tolerate a range of functional groups and is not overly influenced by the electronic nature of the aryl group 2ae. The optimal yields were obtained with more electron neutral groups with phenyl (2a) and 4-fluorophenyl (2b) providing the highest yields $\left(\sigma^{-}\right.$values for these substrates are 0 and -0.03 , respectively). ${ }^{21}$ More electron-rich aromatics (2d and $\mathbf{2 e}, \sigma^{-}=$$0.26)^{22}$ and electron deficient groups $\left(2 \mathbf{c}, \sigma^{-}=0.65\right)$ gave lower, yet good yields. Alkyl carbamates could also be used, producing benzyl amide 2f, albeit in reduced yield. Extended alkyl chains at the $\mathrm{R}_{2}$ position ( $\mathbf{2 g}$ and $\mathbf{2 h}$ ) were well tolerated, as were branched alkyl groups with cyclopropyl $\mathbf{2 i}$ and a silyl tertiary ether $\mathbf{2} \mathbf{j}$ being formed. Aryl groups could also be incorporated at the $\alpha$-position (2k), and substitution on the $N$-aryl ring $(\mathbf{2 k - 2 n )}$ provides the same trends as for the parent substrate. Finally, substitution on the allylic group $\left(\mathrm{R}_{3}\right)$ was examined through the use of the methallyl analog. In these cases (2p-2r), the products are formed in good yields, albeit slower than the unsubstituted cases.

\section{Scheme 3. Reaction of Ketenimine with Sulfur Ylide and Proposed Mechanism}

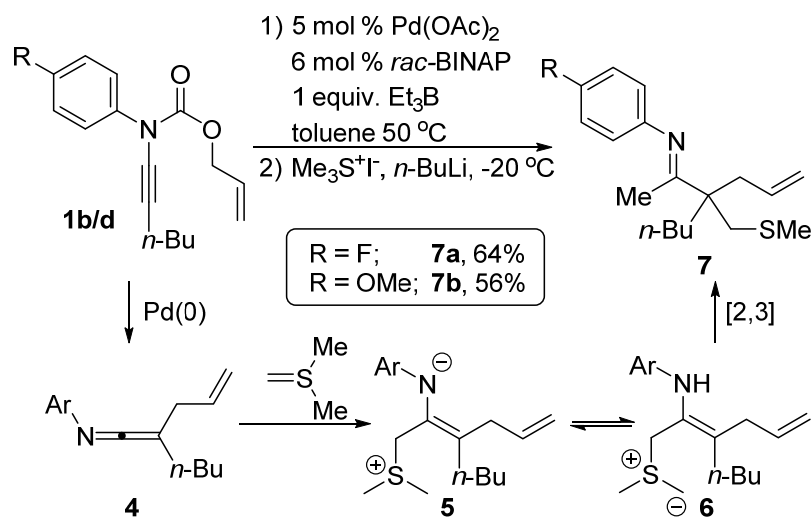

The ketenimine products can also undergo alternative reactions, other than hydrolysis, without isolation. While other heteroatom nucleophiles have been utilized to form amidine and imidate products, ${ }^{16}$ the use of carbon nucleophiles is much less common. When the ketenimine $\mathbf{4}$ is treated with a sulfur ylide directly following the reaction, a rearrangement occurs to provide an imine 7 with a fully substituted $\alpha$-carbon (Scheme 3 ). ${ }^{23}$ This rearrangement is proposed to occur via initial nucleophilic addition to the central carbon of the ketenimine followed by a $C$-to- $N$ proton transfer to provide a second ylide 6 . This can undergo a [2,3]-Wittig rearrangement and following tautomerization provides imine 7 in 56-64\% yield from the $N$-alloc ynamide precursor. The reaction appears insensitive to electronics on the aryl ring with both electron rich and deficient groups providing similar yields suggesting that the proton transfer is fast.

An isotopically labeled alloc group was also synthesized and utilized in the reaction (Scheme 4). This substrate demonstrated the intermediacy of a $\pi$-allyl species by providing a $55: 45$ mixture of regioisomers $\mathbf{8 a}$ and $\mathbf{8 b}$. The product ratio can also provide us with a kinetic isotope effect. The $k_{\mathrm{H}} / k_{\mathrm{D}}(0.82)$ is consistent with an inverse secondary isotope effect suggesting that exogenous nucleophilic attack of the ynamide intermediate is rate limiting. ${ }^{24}$ When this is combined with the reactivity profile observed with substituted phenyl groups this indicates that the buildup of charge in the transition state is remote from the nitrogen, possibly on the reacting alkynyl carbon.

\section{Scheme 4. Deuterium Positioning and KIE Experiment}
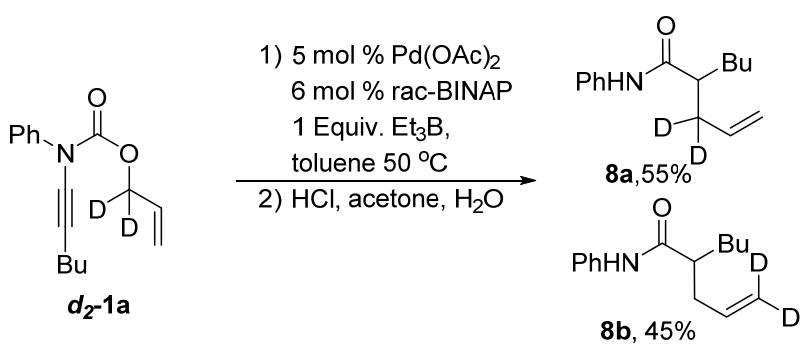

We also conducted a crossover experiment (Scheme 5), where a 1:1 mixture of deuterated butyl substrate $\boldsymbol{d}-\mathbf{1 a}^{25}$ and non-deuterated hexyl analog $1 \mathrm{~g}$ was subjected to the reaction conditions and the reaction mixture analyzed by mass spectrometry. As can be seen in Scheme 2, the very similar butyl and hexyl substrates provide almost identical yields of $\mathbf{2 a}$ and $\mathbf{2 g}$. The resulting spectrum clearly indicates the presence of significant amounts of all four possible compounds in ratios consistent in a statistical mixture. The composition of these ions were confirmed using accurate mass analysis. ${ }^{26}$ These crossover products can only be formed via a dissociative solvent separated ion pair which was not present in Hsung's system. The presence of a bidentate ligand on the palladium alongside the allylic intermediate would not allow an inner sphere mechanism to occur due to the lack of coordination sites available. Indeed, during this mass spectrometry experiment we also detected the presence of the cationic [(BINAP)Pd(Allyl) $]^{+}$complex. This could also indicate that this is the resting state of the catalyst which is prior to the rate limiting nucleophilic attack. We cannot identify which anionic borate complex is present (II or III) but the $[(\mathrm{BINAP}) \mathrm{Pd}(\mathrm{Allyl})]^{+}$complex was the only observable palladium species by mass spectrometry at present at the end of the reaction (Scheme 6). The preference for electron neutral substituents and the observations that TFA was a very selective additive could suggest that the reaction proceeds directly from II to IV. Such a scenario would locate the anion very remote from

\section{Scheme 5. Crossover Studies}

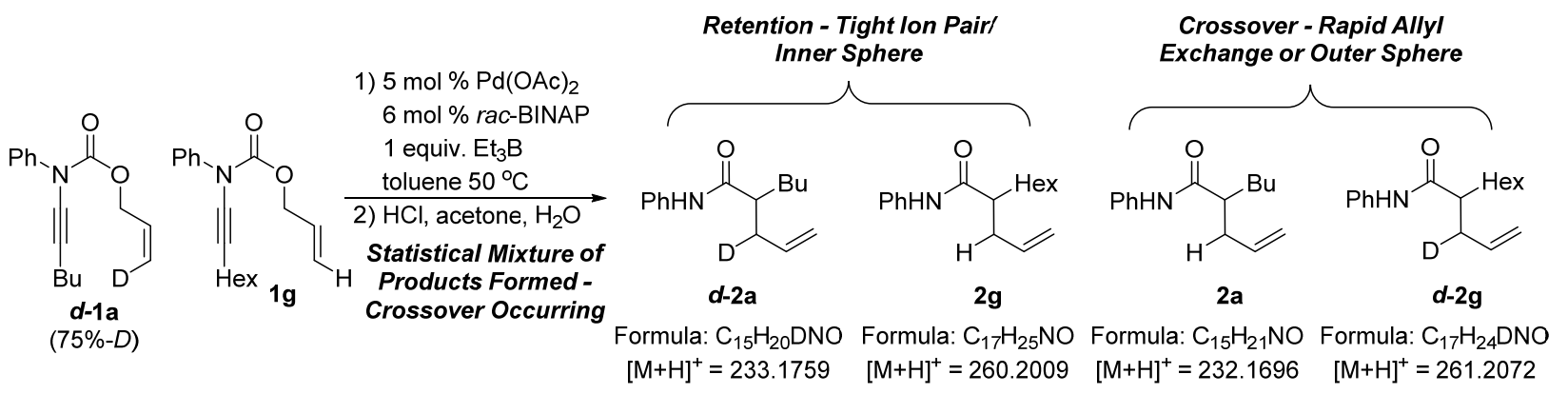




\section{Scheme 6. Proposed Mechanistic Cycle}

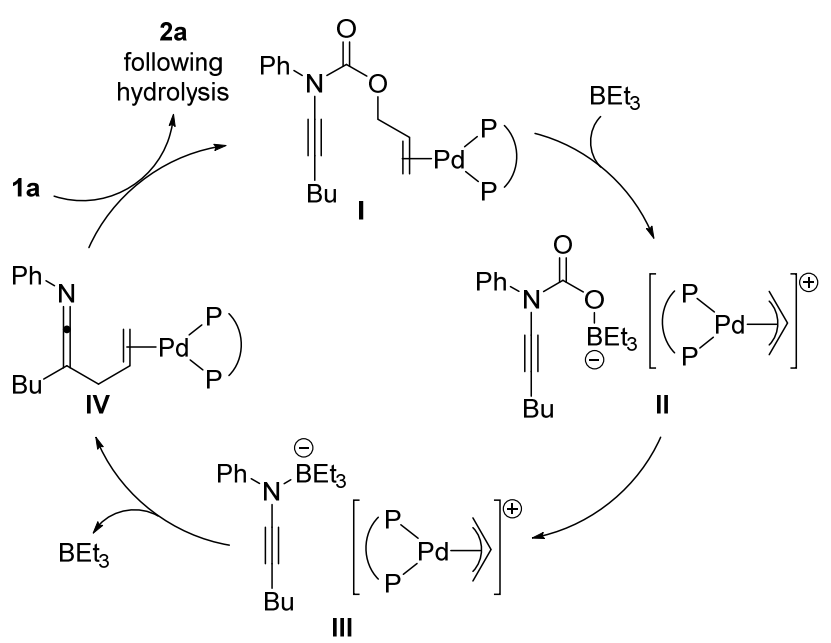

the aromatic group and form a labile carbamic acid derivative when TFA is used.

In conclusion, we have developed a mild and functional group tolerant approach to ketenimines, which circumvent many of the issues encountered in other methods. The ketenimines can be hydrolyzed to the corresponding secondary amide providing a new route, which is especially efficient for non-nucleophilic electron poor anilines. We have also demonstrated other derivatizations of the ketenimine intermediates, reacting them with sulfur ylides and imines. Finally, we have studied the mechanistic pathway of this reaction and found evidence that this is a dissociative outer-sphere mechanism through isotopic labeling studies. These studies have also suggested that reductive alkylation is rate limiting. Extensions of this reaction are currently being explored further.

\section{Supporting Information}

Detailed experimental procedures, full characterization of all compounds reported and copies of NMR spectra $\left({ }^{1} \mathrm{H}\right.$ and $\left.{ }^{13} \mathrm{C}\right)$ are provided. This material is available free of charge via the Internet at http://pubs.acs.org.

\section{AUTHOR INFORMATION}

\section{Corresponding Author}

matthewcook@montana.edu

\section{ACKNOWLEDGMENT}

We gratefully acknowledge Queen's University Belfast, Montana State University and DEL (studentship to J.R.A) for support.

\section{REFERENCES}

1. For reviews of ketenimines, see: (a) Krow, G. R. Angew. Chem., Int. Ed. 1971, 10, 435; (b) Perst, H. Science of Synthesis 2006, 23, 781-898; (c) Yoo, E. J.; Chang, S. Curr. Org. Chem. 2009, 13, 1766; (d) Lu, P.; Wang, Y. Synlett 2010, 2, 165; (e) Kim, S. H.; Park, H. S.; Choi, J. H.; Chang, S. Chem.-Asian J. 2011, 6, 2618; (f) Lu, P.; Wang, Y. Chem. Soc. Rev. 2012, 41, 5687

2. Jochims, J. C.; Anet, F. A. L. J. Am. Chem. Soc. 1970, 92, 5524.

3. (a) Neuman, Jr., R. C.; Sylwester, A. P. J. Org. Chem. 1983, 48, 2285; (b) Molina, P.; Alajarin, M.; Vidal, A., J. Org. Chem. 1992, 57, 6703; (c) Denonne, F.; Seiler, P.; Diederich, F. Helv. Chim. Acta 2003, 3096; (d) Alajarin, M.; Bonillo, B.; Ortin, M. -M.; Sanchez-Andrada, P.; Vidal, A. Org. Lett. 2006, 8, 5645; (e) Yang, Y.-Y.; Shou, W.-G.; Hong, D.; Wang, Y.-G., J. Org. Chem. 2008, 73, 3574; (f) Zhou, X.; Zhang, Z.; Zhao, H.; Lu, P.; Wang, Y. J. Org. Chem. 2017, 82, 3787.

4. (a) Froeyen, P. Acta Chem. Scand. 1974, 28, 586; (b) Capuanao, L.; Willmes, A. Liebigs. Ann. Chem. 1982, 80; (c) Zhou, X.; Jiang, Z.; Xue, L.; Lu, P.; Wang, Y. Eur. J. Org. Chem. 2015, 5789.
5. (a) Lage, N.; Masson, S.; Thuillier, A. J. Chem. Soc., Perkin Trans. 1 1991, 2269; (b) Lage, N.; Masson, S.; Thuillier, A. J. Chem. Soc., Perkin Trans. 1 1991, 3389.

6. (a) Stevens, C.; French, J. C. J. Am. Chem. Soc. 1954, 76, 4398; (b) Lambrecht, J.; Gambke, B.; Von Seyerl, J.; Huttner, G.; Kollmannsberger-Von Nell, G.; Herzberger, S.; Jochims, J. C. Chem. Ber. 1981, 114, 3751; (c) Battaglia, A.; Barbaro, G.; Giorgianni, P. Foresti, E.; Sabatino, P.; Dondoni, A. J. Org. Chem. 1985, 50, 5368; (d) Inoue, S.; Suzuki, O.; Sato, K. J. Chem. Soc., Chem. Commun. 1985, 1773; (e) Moderhack, D.; Stolz, K. Chem. Ber. 1986, 119, 3411; (f) Quast, H.; Bieber, L.; Regnat, D. Chem. Ber. 1990, 123, 1739; (g) Katagiri, T; Handa, M.; Asano, H.; Asanuma, T.; Mori, T.; Jukurogi, T.; Uneyama, K. J. Fluorine Chem. 2009, 130, 714; (h) Jin, X.; Willeke, M.; Lucchesi, R.; Daniliuc, C.-G.; Froehlich, R.; Wibbeling, B.; Uhl, W.; Wuerthwein, E.-U. J. Org. Chem. 2015, 80, 6062.

7. De Corte, B.; Denis, J. M.; De Kimpe, N. J. Org. Chem. 1987, 52, 1147

8. Surmont, R.; De Corte, B.; De Kimpe, N. Tetrahedron Lett. 2009, 50, 3877.

9. (a) De Kimpe, N.; Verhe, R.; De Buyck, L.; Chys, J.; Schamp, N. J. Org. Chem. 1978, 43, 2670; (b) De Kimpe, N.; Verhe, R.; De Buyck, L.; Schamp, N. Org. Prep. Proc. Int. 1982, 14, 213.

10. (a) Stevens, C. L.; Gasser, R. J. J. Am. Chem. Soc. 1957, 79, 6057; (b) Motoyoshiya, J.; Teranishi, A.; Mikoshiba, R.; Yamamoto, I.; Gotoh, H.; Enda, J.; Ohshiro, Y.; Agawa, T. J. Org. Chem. 1980, 45, 5287; (c) Sung, K.; Chen, F. -L.; Huang, P. -M.; Chiang, S. -M. Tetrahedron 2006, 62, 171; (d) Erb, J.; Strull, J.; Miller, D.; He, J.; Lectka, T. Org. Lett. 2012, 14, 2191

11. Shimizu, M.; Gama, Y.; Takagi, T.; Shibakami, M.; Shibuya, I. Synthesis 2000, 517.

12. Firl, J.; Schink, K.; Kosbahn, W. Chem. Lett. 1981, 527.

13. (a) Newman, M. S.; Fukunga, T.; Miwa, T. J. Am. Chem. Soc. 1960 82, 873; (b) Clarke, L. F.; Hegarty, A. F. J. Org. Chem. 1992, 57, 1940; (c) Russel, G. A.; Chen, P.; Yao, C. -F.; Kim, B. H. J. Am. Chem. Soc. 1995, 117, 5967.

14. For a review of silyl ketenimines, see: Denmark, S. E.; Wilson, T. W. Angew. Chem. Int. Ed. 2012, 51, 9980.

15. (a) Chen, J.; Cook, M. J., Org. Lett. 2013, 15, 1088; for an analogous report published similtaneously see: (b) Montgomery, T. D.; Zhu, Y.; Kagawa, N.; Rawal, V. H., Org. Lett. 2013, 15, 1140.

16. (a) Mulder, J. A.; Kurtz, K. C. M.; Hsung, R. P., Synlett 2003, 1379 ; (b) Evano, G.; Coste, A.; Jouvin, K., Angew. Chem., Int. Ed. 2010, 49, 2840; (c) DeKorver, K. A.; Li, H.; Lohse, A. G.; Hayashi, R.; Lu, Z.; Zhang, Y.; Hsung, R. P., Chem. Rev. 2010, 110, 5064; (d) Evano, G.; Jouvin, K.; Coste, A., Synthesis 2013, 45, 17; (e) Wang, X.-N.; Yeom, H.-S.; Fang, L.-C.; He, S.; Ma, Z.-X.; Kedrowski, B. L.; Hsung, R. P., Acc. Chem. Res. 2014, 47, 560; (f) Mansfield, S. J.; Campbell, C. D.; Jones, M. W.; Anderson, E. A., Chem. Commun. 2015, 51, 3316.

17. (a) Zhang, Y.; DeKorver, K. A.; Lohse, A. G.; Zhang, Y.-S.; Huang, J.; Hsung, R. P., Org. Lett. 2009, 11, 899; (b) DeKorver, K. A.; Hsung, R. P.; Lohse, A. G.; Zhang, Y., Org. Lett. 2010, 12, 1840. (c) DeKorver, K. A.; Johnson, W. L.; Zhang, Y.; Hsung, R. P.; Dai, H.; Deng, J.; Lohse, A. G.; Zhang, Y.-S., J. Org. Chem. 2011, 76, 5092.

18. (a) DeKorver, K. A.; Wang, X.-N.; Walton, M. C.; Hsung, R. P. Org. Lett. 2012, 14, 1768; (b) DeKorver, K. A.; Hsung, R. P.; Song, W.-Z.; Wang, X.-N.; Walton, M. C. Org. Lett. 2012, 14, 3214; (c) Wang, X.N.; Winston-McPherson, G. N.; Walton, M. C.; Zhang, Y. Hsung, R. P.; DeKorver, K. A. J. Org. Chem. 2013, 78, 6233.

19. For review of decarboxyaltive allylations and benzylations, see: Weaver, J. D.; Recio, A., III; Grenning, A. J.; Tunge, J. A. Chem. Rev. 2011, 111, 1846

20. Zhang, Y.; Hsung, R. P.; Tracey, M. R.; Kurtz, K. C. M.; Vera, E. L., Org. Lett. 2004, 6, 1151.

21. For a compilation of Hammett and resonance parameters see: Hansch, C.; Leo, A.; Taft, R. W. Chem. Rev. 1991, 91, 165.

22. $\sigma^{-}$values are identical between $\mathbf{2 d}$ and $\mathbf{2 e}$. The additional $\sigma$ withdrawing of the OMe groups render $2 \mathrm{e}$ less electron releasing.

23. Hiro, K.; Sato, S. Chem. Pharm. Bull. 1985, 33, 2331.

24. For reviews of kinetic isotope measurements, see: (a) Gómez-Gallego, M.; Sierra, M. A. Chem. Rev. 2011, 111, 4857; (b) Simmons, E. M.; Hartwig, J. F. Angew. Chem., Int. Ed. 2012, 51, 3066.

25. Deuterium incorporation of $\boldsymbol{d}-\mathbf{1}$ a was $75 \%$.

26. For full details and a full annotated mass spectrum from this reaction see the Supporting Information. 